\title{
A DUFFLE BAG DIARY OF AN AMERICAN RED CROSS WORKER IN FRANCE
}

(Continued from July, 1939)

By Elis E. Wilson

Wednesday 11-6-1918.

Late in getting up. Four fellows in our room. At office, then rode over to Stamford on business, soon returning. Good dinner at Inn. Captain Fellows said he was going over with Company B and advised me that I had better go or I might not get across. Apparently war is nearly ended but there would be plenty of work for the Red Cross in Europe for several months. Sergeant Lundin and I went on short call to Engle home, host entertained us with lunch and liquors. The eaptain gave me the privilege of doing as I wished, go or remain in service at the camp. I shall go. Thankful I have a task to do.

Thursday 11-7-1918.

A false fire alarm was sounded about midnight just to ascertain how quickly the boys could get out of the Inn. It was pandemonium but regardless of all the racket several slept on until guards aroused and brought them to roll call. In forenoon all trunks were carried by owners out of hotel onto lawn and into orchard for inspection of contents. Some articles rejected. Many kodak pictures snapped. Kodaks not allowed to be taken overseas. News came that Germany has surrendered on Allies terms. Major giving out letters of recommendation. Can't leave Inn nor go any place off grounds. A sumptuous lobster banquet, then a dance, then to bed. This banquet outdid all the feasts we have had. Lieut. Hopkins, head cook and generalissimo of the occasion was given a captaincy for his reward and he deserved it. Speeches.

Friday 11-9-1918.

Up at five A. M. Answered roll call. After breakfast Company $B$ marched to Sound Beach depot from Ye Old Greenwich Inn our one month's preparation ended. Boarded train for New York City. All of Company had dinner at Childs' 
restaurant. On street cars to Fourteenth street, Pier 57, inspection of baggage. Passed onto French liner, La Lorraine Took all day. My berth No. 506 with Captain Young, who goes to Italy. Dinner on boat. French people do not have supper, their meals are breakfast, luncheon, and last meal of day, dinner. The boys were given cigarettes a plenty, handed out or thrown to them by people in high buildings which we passed. Meet the prodigals at the dock with a fatted calf when we return.

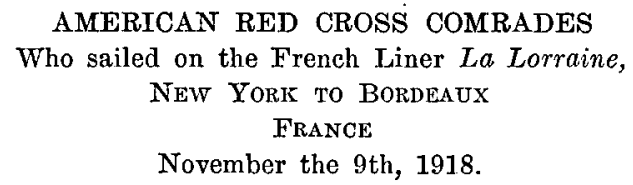

Edward T. Bently
Chas. F. Borncamp
Chester B. Boughter
George Bradford
Charles Brooker
Tim J. Buckley
Roy D. Carlysle
Russell Cessna
F. J. Currier
Mark W. Ellsworth
George W. Ernst
Fred A. Fellows
James J. Harrington
Preston B. Heller
Elmer A. Henckel
Harold F. Hess
Harry H. Hitzman
John E. Jameson
H. C. Jewett

Edward T. Bently

Chas. F. Borncamp

Chester B. Boughter

George Bradford

Charles Brooker

Tim J. Buckley

Roy D. Carlysle

Russell Cessna

F. J. Currier

Mark W. Ellsworth

George W. Ernst

Fred A. Fellows

Preston B. Heller

Elmer A. Henckel

Harry H. Hitzman

H. C. Jewett
Edwin B. Lovejoy

A. W. Marqua

C. C. Mason

F. W. Mason

Howard J. O'Neil

Roy A. Parker

Eugene M. Pattison

Morris D. Payne

William D. Phillips

Walter W. Reymer

John C. Roche

W. M. Roche

Clarence R. Solberg

Farold J. Stussy

Paul Symonds

James A. Thomas

Stuart Ward

F. G. Wells

Ellis E. Wilson

Sunday 11-10-1918.

Boat still at dock. Wrote wife two letters, not sealed. Vessel left pier at ten A. M. Sixty-nine Red Cross men also Y. M. C. A. men, K. C. men and a large number of Zech soldiers. Out of sight of land about three P. M. Three hydroplanes with us overhead, also two convoys, smooth ocean, French crew. We waved good-bye to the statue of Liberty and we know each hopes for a safe return. Many motor boats in bay filled with men and women fishing for mackerel.

Monday 11-11-1918. 
Awoke in berth 506 liner La Lorraine after a fine sleep. One of my grips was misplaced by comrade who carried it for me. Found it later. Was given a suit case at New York pier to deliver to a Red Cross officer in Paris. A breakfast of coffee and bread, but enough. At noon a good lunch was served with many dishes. A little sea sick but ate regular meals. Got acquainted with boat. Several French officers who have been assisting at American Soldier's training camps returning home. Ocean rough. Wrote wife a letter to be mailed later. Radio said armistice had been signed. A few of the boys sea sick, unable to eat and out of sorts, but most of them hilarious and happy. Is it to be a glorious outing?

No more shall kings make man a puppet or a slave

For o'er the world the palm and willow wave.

Tuesday 11-12-1918.

Up at call. Rough waters. Boys studying their French books. Made the acquaintance of Miss Utter of Corona, California, who is bound for Congo country in Africa as a missionary of the Christian Church. A sweet singer. Last ten hours boat traveled three hundred eighty-one miles. Most of boys sick. Ocean turbulent and ports closed. Passengers had to stay on leeward side of vessel. Salt water for washing. At request of Miss Utter wrote my name and town in her address record. She stated she was acquainted with Mary CarpenterCraig of Drake University, Des Moines, Iowa. I told Miss Utter of the beneficent life of Loduska Wyrick who was one of the first graduates of that school to go as a missionary. Her field was Japan.

Wednesday 11-13-1918.

Boat mileage third day three hundred seventy-two miles. A dance last night. Dinner of sauerkraut, pork and weenies tasted good after eating French dishes. Had a lively argument with two French officers and a Polish Russian over prohibition. They denounced it. I upheld it from a scientific and economical standpoint. Stayed with them and verbally fought it out alone until all arguers left me. Some Y. M. C. A. men started the argument but they deserted. Red Cross workers are under no restrictions regulating verbal disputes. Saw sea gulls and dolphins and one vessel. 
Note: This Polish Russian was an able man who had been sent by his government to the United States to investigate our beet sugar industries. After the war started he was ordered to return to Russia but refused to do so. His family fled to Paris and he was going there to join them. He said the Russian government had confiscated all his property and he dare not return as it would mean certain execution for him. He also said that the Russian people would wander in the wilderness of experimental governments for forty years before stabilization.

Thursday 11-14-1918.

Bad air on boat and everyone complaining. A day of big swells at sea. Doors and windows tightly closed. Eating, sleeping, and talking with strangers. Find there are fortythree Y. M. C. A. and ten Y. W. C. A. workers on board. About one thousand persons on vessel. Captain Fellows held a Kangaroo Court which furnished amusement all evening. Did not stay up to see the finish, but the prisoner was fined a liberal sum which was paid by comrades and then disbursed for the choicest liquors sold on the boat.

Note : Non-appearance or personal appearances the following day identified the revelers.

Friday 11-15-1918.

With others slept on deck till after midnight because of bad air in boat, which was caused by keeping doors and windows shut tight. Waves swept over decks. Chocolate only for breakfast. Ate apples from Oregon later, six for twenty-five cents. Gave three missionary ladies to Congo chocolate bar apiece. One suspicious looking craft which we passed, provided a little excitement. Not a German submarine. Only a heavy laden Standard Oil tanker. Boys are not fond of French cooking and continually talk about "ham and eggs." Saturday 11-16-1918.

Atlantic calm, port holes and doors open and plenty of fresh air. Watching for boats but only one seen. Traveled three hundred eighty-one miles last twenty-four hours. Told we would be in Bordeaux Monday. The boys are uneasy about submarines for German Commanders at sea may not know of the armistice. Interesting talk with a Peruvian and his wife. 
Gave missionary girls a box of eandy. Boys eating Oregon apples which cost five cents each. Beautiful moonlight night on sea.

Make for us sky that tender hue, You made that night ere the sun dropped through,

Colors melted in burning air

Flowing I know not whence nor where

Before I die I want to see-

Make the colors again for me.

"No, No." I paint all day

Rose and amethyst, gold and gray

Purple precipice, silver rain

But I never shall paint that scene again.

\section{Sunday 11-17-1918.}

Anon.

Beautiful balmy morning in Bay of Biscay. Latitude 45 degrees, longitude about 40 degrees. Saw several vessels. Rev. Moon, a Congo River missionary of the Christian Church preached sermon in library room. Gave his wife five dollars, it being her birthday. Gave one of boys one dollar, his money all gone. Bought candy for Peruvian and his wife. Had chicken for dimner. Boys anxious to see land. Talked with Capuchin fathers.

Note: These Capuchin fathers, young men with beards, never shaved, said they came from Quebec, Canada, and were going into Spain to do missionary work, well educated. The missionary group of the Christian Church were to remain in Bordeaux until they could get passage on some vessel to Congo River country, Africa.

Monday 11-18-1918.

Very cool on Bay of Biscay today. Breakfast of chocolate, bread, oatmeal, no trimmings. Bought a peck of Oregon apples for the boys as nearly half did not get up for breakfost. Fixed up my army roll. Hash for lunch and plenty of olive oil. Had my hair cut by French coiffeur, sixty cents. Boat swerved and circled and passengers were excited thinking it might be a submarine. Some curious maneuvers. Perhaps floating mines.

Note: French sailors were very cautious in these waters to avoid explosives floating near entrance of Gironde river, France. When the Peruvian and his Spanish wife returned 
to their deck chairs after dinner, a fine wool robe of beautiful design and color was gone, stolen of course. Seldom is anything taken on a vessel until it is about ready to dock for then there is no time to search for lost articles. This man had an appointment as consul from Peru to Spain. Was land and copper mine owner. Wished more Americans would come to his country to aid in its development.

11-19-1918.

No sleep last night, all excitement. Entered Gironde river, France, last evening, avoiding anchored mines at its mouth placed there to destroy German boats. Our vessel changed its course abruptly at right angles several times, the pilot knowing the location of the French mines. Busy times getting baggage lined up ready to depart. Reached Bordeaux about fifty miles inland in the night, tide went out and our boat rested on Gironde river bottom. Had breakfast. Met by Red Cross men stationed at Bordeaux. Marched up town. Trucks took us around to see some of the sights, visited old Moorish town. One-horse carts, donkeys. Women with brush brooms cleaning streets. Bought a French paper. Had lunch at Red Cross canteen. Took train at Bordeaux for Paris. Paris, coveted goal of the Kaiser Wilhelm, never reached. Arrived at nine P. M. Feudal castles still stand on highways. Interesting ride. Company got into army trucks in Paris and were taken to barracks at St. Cyr, some eighteen miles from Paris, passing through Versailles. Hundreds of war-wrecked autos lined up along the avenues.

Note: Train passed through sand hills and vineyard, the wine producing section. Along railway were prison camps, where large numbers of Germans were held under guard by the French. A tall negro in an American uniform was hiking southward, perhaps he had started home. Nearing Perigeaux the trainmen said there would be French Croix Rouge women at the station. The boys visioned sandwiches and coffee. The women were lined up with their big tin cups and asked for money for the blessés, wounded soldiers. The boys were generous; through Limoges where china ware is manufactured; Chateraureaux located on left bank of Indian river in a level country; and Orleans whose name was given to 
France's most famous daughter. Paris, the city of dreadfal fears, was in darkness. One boy shouted "There's the Eiffel tower, we are in Paris sure." In 1806 Napoleon transferred to St. Cyr the famous military academy he had founded in Fontainebleau. It is the West Point of France. Some of the stone buildings erected by Napoleon are still in use. Wednesday 11-20-1918.

The cold damp fog shivers me, shivers everybody. Getting the lay of the land. Chateaux grounds about one acre. Garden, pear and apricot trees. Brick and cement house. High ceilings and fire places, tile mantels. Story told that a Frenchman murdered his wife and two children here and then suicided. It is spoken of in the neighborhood as a haunted place. The boys would like to see the spirit apparitions. Filled out a long list of papers in order to secure a French passport or permit to go upon the streets. Every new resident of a French town must be recorded. St. Cyr is an historical place. Plenty of wine shops. In Guard detail. Heard in the darkness; "Halt.." The man in khaki stopped at attention. "Who are you, what are you and where are you going?" "Well I thought I was a Red Cross worker but I must be nothing going nowhere." Half dozen of boys on guard duty all night for various reasons. The chilling effects of the dampness and coldness were somewhat relieved by frequent visits to the wine shops. Kept open to accommodate the Americans who are supposed to have money to spend.

Thursday 11-21-1918.

Up with bugle. Army breakfast. Company took a hike to business district of St. Cyr. After lunch took another hike to French Commissary where they were baking one hundred thousand $(100,000)$ loaves of bread per day. Making sausages out of horse, hog and beef meat for French soldiers. Visited winery where we had all the bitter wine we could drink and some drank all they could. Let us go out in evening to country but not into town. Cool all day and boys can't get warm. Air is very damp. We have a stove in our room. Seven of us. Main part of German high seas naval fleet surrendered.

Note: The Chateaux would not house all the company. About twenty were quartered in what had been the servants' 
quarters, which were in the second story of a brick barn, plastered, well furnished rooms. There had been no horses kept in barns for a long time apparently. The stalls had been turned into pens for rabbits of which there was perhaps a hundred. Rabbits furnished about the only meat these villagers had. The baking of bread, the making of wine and making of cured meats was continuing with a full force of workers. The bread was mostly made of rye and with a little wheat and barley flour. The mixing or blending of the wines was done in great cement underground vats and as we were informed by the workmen, consisted mostly in putting a certain per cent of grain alcohol in the wines to give it more pep. The truth about such liquors and the resulting outcome was that the French armies never initiated any forward movement of consequence nor went over the top until the Americans came to their aid. Mentally and physically stupefied the French soldiers died in their trenches. The wines they drank destroyed their efficiency. I do not say this of all of them. Liquor supplies during the long siege at Verdun and vicinity were limited and there alone on all the battle front did the French soldiery hold the Allemand in check against the most terrific battle onslaughts the world has ever known. Leaving the commissary, the sergeant blew his whistle for the company to fall in line ready to march back to the Chateaux. Blew it several times. Finally all were out of winery and lined up on highway. Orders were given to march but the lines broke and few could keep step. Ordered to halt. The sergeant made a speech threatening punishment if his orders were not obeyed. "Here on these very boulevards a century ago Napoleon marched his well trained soldiers and today a few squads of Americans can't keep step, etc." Again the order was given to march when officer shouted: "Break ranks, go home any way you damn please. You're all drunk, hic." With friendly assistance and a few autos all got home including the sergeant.

Friday 11-22-1918.

Cool, fine day, St. Cyr, France, near Paris. Boys all having a good time getting papers made out ready to go to work. Company drilled on aviation school grounds in afternoon. All in fine physical condition but many short of money. Several 
of us went into St. Cyr business district. All dark, no street lights, small lights in houses. Sky full of airplanes during day. Cannon roaring from practicing so we are told. Sunny France. Company took in barefoot kid and cleaned him up.

Note: The military authorities kept all orders in force until certain there would be no further outbreak of hostilities. Especially were airplanes feared; renegade aviation. It appeared as though the people loved to hear the deep roar of the cannon. Several of the boys took airplane rides with the French aviators but it was dangerous for some were students. A collection was taken for the barefoot boy. He was given a new outfit of clothes, also a bath with soap. The second day his father appeared and took his son home, very grateful for what the Croix Rouge Americans had done for him.

It was an event the boy will surely remember for besides his new clothes he took home a generous lot of chocolate candy and several cakes of soap.

Saturday 11-23-1918.

St. Cyr, France, is a military center. We hiked to army aviation field but gate was closed and did not get in until afternoon when thirty-two of company were taken through. Large army field. Grass pasture of two-hundred or more acres with thousands of old and new flying machines. Building new ones, tearing down old ones. Plenty of plain food. With others rode on street cars to Versailles and looked at castles and into shops. City in darkness. C. B. Boughter, an artist, put masonic emblems on walls of our room. Seven of us each having a cot. Comrade Boughter blistered a heel while marching which developed seriously and returned to U. S.

Note: The latitude of Paris corresponds nearly with that of Winnipeg, Canada. Our days were short and without electric lights, the night seemed long.

Sunday 11-24-1918.

Called at six A. M. Cleaned up room. Cream of wheat for breakfast. No milk. No church for protestants here that I have seen. Drilled on green for benefit of Major Osborne, head of A. R. C. in France. After dinner with Sergeant Payne and others went on street cars to Versailles where we put in 
afternoon looking over Chamber of Deputies and other buildings and sights of the historical eity. In the evening with F. W. Mason, or was it his brother C. C. Mason, took a long walk into the country on a well kept road going almost to the noted sheep town of Ramboulette. The stars shone brightly, the farm dogs barked, the air was invigorating but there was a strange weirdness in everything else that seemed uncanny for we were aliens.

Monday 11-25-1918.

Rain all day at St. Cyr and boys stayed in rooms. Some are tired of being cooped up so long. Took subway car at Versailles and went to Paris, Place de la Concorde, to deliver to Captain Hutchins satchel given me in New York City, and did so. Found him at Hotel Regina. Dinner of small steak, fried potatoes, roll and chocolate, two dollars, American money, but they got no tip from me. Took surface car back to St. Cyr through Versailles. Stayed in room in evening. My first day in Paris. Kept dinner bill as a souvenir of war time prices.

Note: American Red Cross Headquarters in Paris had been moved from No. 4 Place de la Concorde to Hotel Regina in order to have more room. Place de la Concorde is considered the most magnificent public square in the world. The Luxor Obelisk, brought from Egypt, marks the center of the square and nearby is the place where in $\mathbf{1 7 9 3}$ the guillotine stood. On the south side of the square flows the Seine River from east to the west.

Tuesday 11-26-1918.

Around St. Cyr Barracks in forenoon. After dinner Dr. Wentworth came from Paris and gave a lecture. Eight sergeants appointed. Told me to get ready to go to Paris with him. Packed ny roll, grips, trunk and accompanied by Captain Fellows, a French chauffeur to drive auto, we were taken to Hotel Borghlese, 2 rue Borghese, Neuilly sur Seine, Paris, which is headquarters for A. R. C. workers in transportation department. Assigned to a room. Good supper. My baggage did not arrive as expected. Truck delayed. Barracks were crowded with workers. St. Cyr was like a prison.

Note :

At the noon lunch the Red Cross doctor gave a talk 
about the evils of Paris and how to avoid them after which several assignments of workers to various stations were read. I was ordered to report at Buffalo Bill Park Garage located near Neuilly sur Seine. Intimated to my superiors that it seemed doubtful to me that I would be able to find a Buffalo Bill Park in Paris but was told that it was the square where Buffalo Bill Cody of Nebraska held his wild west show during last Paris exposition. A French chauffeur in a Ford touring auto drove the lecturing doctor, Captain Fellows and myself from St. Cyr through Versailles and St. Cloud to Paris. As we were passing through Bois de Boulogne, the ancient park along the Seine of over 2,000 acres, the chauffeur suddenly slowed up the auto and said, "There is Marshal Joffre." The doctor asked if he might not be mistaken and he answered that he was sure of it for he knew him well by sight and then added, "Don't you see one hand is gone?" Joffre was coming from the woods to the boulevard where an auto was awaiting him. A fine figure in blue uniform with gold braid; a greater leader in the world's conflict. Farther on our auto stopped and permitted the open auto of Marshal Joffre to pass. He sat alone in the rear seat grim, grieved, grizzled, but with a soldier's hauteur.

No. 2 rue Borghese, Neuilly sur Seine had been secured as barracks and at this place most of American Red Cross workers of this contingent made their home. Neuilly is a beautiful suburban residence spot outside the walls of Paris. There are many shell wrecked mansions.

The barracks were built for an apartment house and barely completed when the war started and had never been occupied. It was said all the male members of the family owning it had been killed on the battlefields, and the heirs rented it for a nominal sum to the American Red Cross because of the generous assistance extended to France and her allies by the people of the United States. A substantial stone trimmed, brick building finished inside with white marble. Large plate mirrors, which in appearance, doubles the size of the rooms. The dream of some architect and a monument for the dead soldier owner, and it should stand for centuries, if not destroyed by war. 
I was given a ticket reading one pa[i]n which entitles me to buy one loaf of bread at any French bakery in Paris.

Wednesday 11-27-1918.

Reported for work at Buffalo Bill Park Garage. Taking ambulance and auto numbers as they come into garage or go out. Damp all day but have a comfortable place. Wrote to wife in evening after locating a Y. M. C. A. run by a pastor in his church. Two large French hospitals near. One the Pasteur Institute, now known as the American Ambulance Hospital. Boys are pretty slow with their work, many dodging. This seems to be a district occupied by well to do French people. An English Episcopal church in same block as hotel. Hotel Borghese is eight stories high with marble trimmings, splendidly furnished inside.

Heard in the barracks :

$$
\begin{aligned}
& \text { Under the hill and over the swale, } \\
& \text { I am driving the muddy trail } \\
& \text { Camouflaged car with noiseless tires } \\
& \text { Through shell holes and sharp barb wires } \\
& \text { Doughboys dying and hell overhead } \\
& \text { I pick up the living and leave the dead. } \\
& \text { Back from the battle, I'll go mighty fast, } \\
& \text { Ho-lo-o, this trip is my last. B o o m. }
\end{aligned}
$$

Thursday 11-28-1918.

A good sleep after taking a bath. Plenty of hot water. Steam, also hot air heat and a fire place in each apartment. Up at sound of gong. Oatmeal and milk for breakfast. Meat plenty for a war country. At Buffalo Park office. Not much doing as it rained all forenoon. Dinner at 11:30. Started to go into Paris but it was raining too heavy. Do not want to get my feet wet. King George day in Paris. Thanksgiving day for Americans. French have made afternoon a general holiday. Took laundry to a woman in a fine house. Hotel Borghese 2 rue Borghese, Neuilly sur Seine, France. Many fine mansions are occupied by the servants, male members all killed and women and children gone to south France away from danger, leaving their servants in possession of their homes but without money. Rubbers nor overshoes obtainable. We could have brought rubbers from United States if we had known how badly they would be needed. Had turkey but it 
was minus the many trimmings we have at home. Cut up with a cleaver.

Friday 11-29-1918.

Up at six o'clock and had breakfast of cream of wheat and milk then reported at office Buffalo Park at 7:00 A. M. Early for me. Enjoyed my first day's work. Put on high rubber boots and left my shoes at quartermasters to be repaired. Interesting talks with boys coming in from front with autos and ambulances. Four from Chateau-Thierry. Some autos sent out for repairs. Buffalo Park is named after Buffalo Bill Cody who used it as a show ground at one time. Paid one franc for a few dates. Fruit is very scarce and high. In France but hardly realize it. Americans in uniform everywhere seem to overcome the foreign atmosphere. A cootie in my hair. Grab him, smash him. A traveler. He didn't hatch on me. A camion driver says of Belleau Woods,-

The shell torn woods are damp

Red blood still moulds upon the ground

I stir the Autumn leaves

A piece of human flesh is found

I listen for the moans of men

The shrapnels shriek, the cannons roar

Heavenward look for rainbow flares

But they are seen or heard no more.

\section{Saturday 11-30-1918}

We are not here to dream and drift but to uplift. A busy day in office. A plenty of good food for hungry soldiers. Ground frozen. After evening dinner went to Paris from Neuilly. Met Mr. Upham on avenue and we were together all evening. Visited Sailors and Soldiers Club and bought some hot chocolate. It was fine. Then to show in Y. M. C. A., Palais de Glace near Avenue des Champs Elysées. Home to rue Borghese at eleven o'clock. Cooties biting my neck. Smash them. Got out my fine tooth comb.

Wrap both your elbows tight around your neck

And seratch, serateh, scratch.

Don't stop a moment, if you do by heck

Cootie eggs will start to hateh.

Sulphur salve makes the devils worse,

They don't mind a soldier's curse. 
So wrap both your elbows about your neck And scratch, scratch, scratch.

-Soldier Song.

Sunday 12-1-1918

\section{DECEMBER}

Worked in office all forenoon at Buffalo Park garage, also most of afternoon while Captain Garland was away. German police dog barking as no one fed her. Went to Episcopal Church in Neuilly in evening but no services were held. Talked with a few of the parishioners. This English church has an interesting history. Hardly know it was Sunday because of business transacted. Wine shops open. Men and women at tables drinking; emotional gaiety. Remainder of Company B except one Sergeant Fowler left as caretaker, came from Chautaux at St. Cyr to barracks at rue Borghese ready for work.

Note. The black German police dog had been brought from the front to Buffalo Park garage by some of the ambulance boys. Trained by the Germans to hate the French, she was chained near the main entrance to frighten away inquisitive French people. One pompous Frenchman failed to see the sign "Beware of the Dog" in two languages and walking within reach, Blackie pounced upon him bestowing a few German dog bites. Blackie knew a Frenchman, regardless of uniforms. A. R. C. paid the man his claim for damages.

Sunrise $7: 49$. Sunset $3: 53$.

Monday 12-2-1918

At office and busy all day mostly checking in and out autos and ambulances. Keep record of numbers, every auto and ambulance having a number in large figures on hood. About twenty Frenchmen employed as mechanics and at general repair work on transports. Are paid their earnings at close of each day. Mostly ex-patriates who with their families would suffer if A. R. C. did not give them employment. Daily I pass a strong wrought iron gate and hear the cry of homeless children. Stone walled asylum for orphans.

Tuesday 12-3-1918

At office in Buffalo Park. Got along fine. Cloudy and very dark. Wore rubber boots. Chauffeurs come into office, 
sit down and fight cooties. Garage grounds are level and solid, water does not sink away. Ordered covered with clean sand, but in a few days bad as ever. We have to wade around in three to four inches of water, oil, sand and refuse. Everyone wears rubber boots causing cold feet. A chauffeur accidently started a chassis which he was repairing and the runaway made the French workmen scatter until it bumped into a camion and was wrecked.

Wednesday 12-4-1918

Paris and vicinity is a land of clouds and mud. People have fine white complexions for the sun seldom shines on their faces in winter time. Did my duty for A. R. C. at office and wrote a letter home. Yesterday while very busy at close of day two drivers came into the office saying they had delivered from another garage a repaired chassis, it stood at the door, asked me to sign a receipt for it which $I$ did and told them where to park it which I should have done myself. This morning in checking up autos the chassis was gone. But it was found. Vigilance necessary to keep autos from disappearing.

Note. The officer over me should have been at the office to help at the cvening rush but he did not appear. Later I learned he had been carousing at a nearby wine shop.

Thursday 12-5-1918

King of Belgium parade. I did not go on streets of Paris till evening hut saw finish of cavalcade. Boulevards crowded with people and vehicles. Went downtown alone on subway. Guards of horsemen and footment with javelins, halberds, muskets and swords made an impassable cordion around his majesty. Royalty of Europe had heard something about the twilight of kings and seem intent upon dazzling these mercurial people with the patrician splendor of hereditary rulers. A plebian from a democracy may visit Paris shortly. I asked a French lady what impression the arrival of American troops in France made upon the citizens. She answered, "We knew it was our only hope. The Allies were beaten. We were fearful. We were dumb. We simply hoped." I asked a gray haired Frenchman the same question and he said, "Sir, when I saw your men in khaki marching through the streets of Paris, 
I said, they are like the soldiers of France in the days of Napoleon."

Friday 12-6-1918

Traded khaki suit issued to me in New York City which was not large enough for order to get a tailor made uniform. Cloudy all day, wore high rubber boots. Mr. Garland received his Sam Browne shoulder straps. Reports say President Wilson is on his way to France. Shell shocked A. R. C. fellow from the front in barracks is to sleep in Lieut. Benson's cot. Benson has gone to Havre. Received three letters from wife which Company C. brought from Sound Beach, Connecticut. Hair cut short to make Hades for the cooties.

Saturday 12-7-1918

Up at six o'clock. Very dark. Put on shoes. Have worn rubber boots all week. At Buffalo Park. Garage closed in afternoon. Up town and looked around trying to habituate Paris streets and landmarks. Eiffel Tower, Arc de Triomphe, Pantheon, Notre Dame, and the Invalides are high sign posts while the Seine river flows from east to west, but if one follows a circular street on way to some goal-lost. Paid seventy cents American money for package of dates, about twenty in carton. Almost impossible to obtain fresh fruits and only at high prices. Visited National Library which is said to contain a million books and is undoubtedly the largest library in the world. Founded by Charles V. During the Revolution many precious collections of manuscripts, maps, prints and medals were confiscated from monasteries and convents and placed in the library by his orders.

Sunday 12-8-1918

At Buffalo Garage in forenoon. In afternoon rode on subway cars to Bastile, but the Bastile is gone. A Frenchman showed me where the guillotine stood. A large monument now marks the location of the fort but it was covered with bags of sand. Walked cast along Rue de Rivoli, street of the river, a long distance until I came to the Tuilleries and Place de la Concorde there took subway to Neuilly sur Seine. Arrived in time for supper. All small shops were open along streets.

Note: Sand bags were placed all over and around the monument to protect it from German shells. The fort, also 
used as a prison, was really a castle built in the fourteenth century. Later it became a place of the blackest tyranny. Here by unjust judgments hundreds of good French people were imprisoned or slaughtered. It is said the Bastile wrought iron key seven inches in length is now in a glass case in the main hall at Mt. Vernon having been presented to Washington by Lafayette.

\section{Monday 12-9-1918}

Work at garage all day. Informed that I was to have charge as bookkeeper at a new hotel or barracks that was being opened at Louis Blane for A. R. C. men in northeast Paris. So quit work at Buffalo Park Garage tonight. With Messers Wells, Payne and Brooker, went downtown to Masonic Club gathering. Masons present from every state in U. S. except two. Passes required to remain out of hotel after eleven o'clock. Sun shone for a few hours the first time in two weeks. Bolsheviks say to kill every man who uses a tooth brush. Night winds murmur through the forests of Boulogne which are near the barracks.

Tuesday 12-10-1918

Got up at six A. M. as usual. Rainy. Walked down Rue de la Armee. Past Are de Triomphe to Champs Elysées until I came to Rue Victor Emmanuel which I found after a long search. A French girl finally piloted me to the street number wanted. Was measured for a new khaki suit to be made by French tailors. Walked back home to 2 Rue de Borghese in time for noon lunch. Got my repaired shoes and a rain coat from Quarter Master and turned in pair of overalls and rubber hat. Have the eity environs around Neuilly pretty well familiarized. Paris streets are not square with the world. Many are circular and it is easy to get lost. "Perdu," says the Frenchman when asked directions.

Wednesday 12-11-1918

Hell broke loose fast auto driving by Americans on boulevards. No limit. Auto came to rue Borghese Hotel and took Sergeant Ed Mars, myself and sixteen of the boys with baggage to Hotel Louis Blane, No. 2 rue Louis Blane, located about four miles away. Sergeant Mars and myself are to have charge of this antiquated habitation which is being remodeled 
somewhat. Major Osborne here for an opening dinner. Turkey served. Place is a damp ancient structure of brick, stone and cement. Large wooden beams. Formerly used as a hotel, wineshop and livery stable. Close to canal Marten. Made up books and gave boys passes to go on street for the evening. Everybody in hotel at eleven o'clock and soon to bed. Single cots with mattresses and plenty of wool blankets make comfortable couches. A little French charcoal stove in each room, toy heaters. Not satisfactory and it becomes necessary to set up big coal burning heating stoves in the halls to dry out dampness. Coal costs about sixty dollars per ton. While this place is an antiquated hostelery, it is a new location for the A. R. C. Has been used as a camp for refugees, from devastated regions. A hall between guest room and the horse stalls. Partitions removed and space used for storage of coal, vegetables, ambulances, etc. Picked up several brass harness hook novelties to take home, souvenirs.

Note: A desk was kept in which all transients were required to register and the daily events and happenings of interest at the hotel were recorded. I am informed that this record book is in the archives of the American Red Cross at Washington, D. C.

\section{Thursday 12-12-1918}

Up at 6 A. M. Dark. Cleaned up desk and called the boys by sounding an auto horn. Mailed hotel letters at local P. O. station. Walked to the east over canal Marten bridge to center of Louis Blanc. Looked over markets. People appear very poor in this quarter of the city. Vegetables a plenty. Inferior grade of clothing in shops. This section I am told is the Apache district of Paris. The French government forced those living here who were subject to military duty into the service. Most were put into front ranks of the army and of course were killed. Many hid in the sewers and limestone caverns under the city. These dwellers along the canal appear to be a degenerate class and in appearance resemble the Apache Indians of southwest U. S. and are just as treacherous. Took a long walk following elevated railway so I could find my way back to hotel. The Swiss houseman who speaks French, German, and English having lived in the United 
States for several years, warned me that the steel shutters in front of big plate glass windows should be dropped at dusk or the windows would be shattered before morning. My answer was that if any Frenchman wished to harm the A. R. C. let them do so. That we must have a light in our window, an open door and always be ready to welcome soldier boys who may be wandering on the streets, perhaps lost. Often deserters. old Glory hangs over the door and there is a light in the window.

Note: One flag was stolen. Incident recalled to me the song sung when I was a small boy:

There's a light in the window for thee, brother,

There's a light in the window for thee.

Though its beams you may not see, brother,

Yet there's a light in the window for thee.

Friday 12-13-1918

Up at four A. M. Called the fellows at $6: 30$. Breakfast at $7: 00$ A. M. Dried my shoes. Took long walk seeing Avenue Bellville market, one mile or more of everything. People jook needy. Drink too much in my opinion, waste time. Their cupboards are always empty. Bought a French alarm clock. Upon the cement paved avenue in the center, lay in order and sometimes in confusion, everything imaginable, watched by its owner, old clothes, trinkets, childrens toys, furniture, cheap jewelry, slices of pumpkin, live chickens, canary and other song birds, dressed chicken cut into pieces, so much for a leg or wing or its gizzard, the head and entrails laid on a paper is salable. A weeping mother trying to sell her dead child's clothing.

Note: Cold feet. There were no rubbers or overshoes to be had in Paris. How many soldier boys died from wet feet, nobody knows. Army pride I presume would not allow soldiers to wear rubbers, but at what price in lives of soldier boys. St. Helena, isle of Napoleon's exile, making ready to receive William Hohenzollern, ex-kaiser of the German empire, but the Queen of Holland permits him to remain at Doorn.

Saturday 12-14-1918

Up at 5 A. M. Three hours before daylight. Opened office. Tooted the auto horn to arouse auto ambulance drivers at $6: 30$. 
Made up books. At 9:15 called Sergeant Mars. Took subway at Louis Blanc for Palais Royal. Went to Tuilleries Gardens. President Wilson arrived at this point of the parade at 10:30 A. M. French soldiery three columns deep barred the crowd which was very large. Walked to Place de la Opera and watched the people. Many American and English soldiers on streets. "Ecee homo," "behold the man," some one said. Vive Wilson shouted the throngs. With him rode President Poincare followed by Clemenceau and other high dignitaries, military, political and social. People hilariously enthusiastic in their receptions of the pacific prophet who insists upon a peace treaty that will end all war. I rejoice to be an eye witness of such a notable occurrence in the world's history. Dinner at French restaurant. Back to Louis Blane in subway at 4 P. M. Talked with French children at hotel door. Gave them gum and candy. It did not rain today.

Note: When President Wilson came to Paris his welcome was dynamic and dramatic. No potentate, so the French people with whom I talked said, had ever received such a gracious welcome-a spontaneous outburst of appreciation for the noble American Commoner who had done so much for their country and humanity. The noisy plaudits of centuries given kings and queens never equalled it in sincerity.

\section{Sunday 12-15-1918}

Up at five A. M. Bought a French newspaper. All I can get in this part of the city. Gave Sergeant Buckley a frane to buy English or American papers downtown. No church, no anything in Paris for most of people. Shops open. In afternoon visited Tuilleries. The gardens are located on the site of a former tile (tuiles) factory. Beautifully laid out spaces. Flower beds, fountains, and monuments, replace a former palace which was partially destroyed by communists in 1871 and later torn down. The Gardens extend from the Louvre to Place de la Concorde. A free promenade.

Monday 12-16-1918

At Louis Blanc Hotel all forenoon. Makes French maids hustle to feed hungry ambulance and truck drivers at noon hour. In afternoon went downtown on surface street ears. Got on at Louis Blane station and off at Place de la Opera. 
Saw President Wilson and his wife as they passed in the cortege. Col. E. M. House was with them. This was a second ovation largely attended by the ladies who blocked the sidewalks. Walked home and wrote to wife. Sent her French papers.

Note: Woodrow Wilson dressed in a black frock coat and high silk hat with his wife riding in an open auto passed along boulevards heralded as the deliverer of France, the triumphant savior of civilization from destruction, the peace leader of the world and finally to be reviled, scorned and belittled by selfish American politicians because of his ideals. Nevertheless what he accomplished will always remain a part of our nations glory.

Tuesday 12-17-1918

No 4 rue Louis Blane, Paris, France. Here is where I stay in the ancient hotel now known as Louis Blanc Barracks. In afternoon went to Place de la Opera and walked back on rue Lafayette as I did last night for I need the exercise. Bought tooth paste, vaseline, and shoe polish at Louvre Department store. Mailed wife a map of Paris. Little trouble to make oneself understand in the large stores.

Wednesday 12-18-1918

At Louis Blanc. Downtown in afternoon. King of Italy in Paris and I mingled with the crowd. Finely dressed men and women on streets. I Large assemblage lined Champs Elysées. Shop windows held lavish displays of sparkling jewelry and fine clothing. When a king with his retinue is the city's guest such a showing is undoubtedly appropriate. Another cavalcade with a king at its head traversed the boulevards. The people cheered but not all of them. Glittering steel kept everyone at a distance from the Italian Roi. Got lost on the streets which is a common occurrence, but kept talking a mixed jargon till I made the natives understand.

Thursday 12-19-1918

In office. Settled with Miss Robertson. Paid her money collected from transients. No mail from home since arriving in Paris. But I am not the only one.

Note: Miss Robertson said to be a Scotch lady, was well acquainted with Paris, spoke several languages, had given 
freely of her money and time to help the Red Cross work. She was treasurer of certain funds and overseeing matron of hotels.

Friday 12-20-1918

In afternoon took subway to Neuilly and left Lieut. E. T. Bentley's watch to be repaired with jeweler there. Then to tailor shop but suit was not ready. Walked to Place de la Opera then home. Some boys are getting to be bats, owls and night hawks. Captain Fellows with us for dinner. Bought an ivory handled Sheffield knife for five franes. The one I had carried for many years I loaned and it was not returned then I started to use a fine one given to me by A. R. C. and it was stolen from my desk. Complained to Mrs. Bauer, the matron, about knife being taken and she said these girls from the devastated regions would pick up anything of value. Should be careful about small articles.

Saturday 12-21-1918

In office all forenoon while Sergeant Mars slept. Duties kept him away all last night. Mailed papers to friends at home. Went to Buffalo Park and drew two weeks wages, one hundred and forty-one franes sixty centimes. Walked home on Lafayette St. Man putting up more stoves in hotel. Gave two waiter girls a franc apiece. The little French charcoal heaters with a two-inch stove pipe do not dry damp elothing of the ambulance chaulffeurs, so it is necessary to put in still more big coal heaters. Waiters and chamber maids have nearly all lost relatives in the French army. Many are widows, poverty stricken. Our boys are generous tipping them with money, also giving small presents. I often act as valet for the coal bucket. These French never before knew the comfort derived from a red hot stove on a raw rainy day. Extravagant Americans they exclaim.

Sunday 12-22-1918

Rain and fog all day. Lamps light. Sergeant Mars and I moved to a room on third floor, quiet place. Wrote to wife and sister. Sent French papers to Professor Hukil of Waterloo, Iowa, for students of the language. Paris people do not observe Sunday like Americans. Presume they carry on the same now as when the battles were raging. Mud and wet. 
City lights in our arondissiment failed and the A. R. C. at Louis Blane generated electricity for hotel with gasoline engine.

Monday 12-23-1918

Started day at five o'clock. Sergeant Mars slept until one o'clock. He remains up late at night while I retire by nine P. M. and arise early to get ambulance and auto drivers started to their work. Bought and read French newspaper. Called on tailors at Avenue Emmanuel III. Suit too small, a new one to be made. Went to A. R. C. commissary and purchased small articles for various persons at hotel. Visited Lafayette Galleries, a department store. Collected six franes from transients. Miss Robertson called at hotel. These tailors pretended to make suits but the truth is they can go to the American Commissaries and buy ready made khaki ones which will fit applicants and call them tailor made. Believe we get better goods. In my case they failed to find a suit that would fit and finally really made one.

Tuesday 12-24-1918

Visited Bellville market place. After dinner, followed elevated line to the Church of the Basilica or Sacred Heart Church, not finished, services being held. These ehurches in France belong to the state and not to the Roman Catholie ehurch so I am told. The Roman congregations rent them for a small sum yearly. Captain Fellows here for dinner. Wrote to wife and mailed her "Almanache." A Christmas eve in Paris, nothing doing, the people celebrate New Years, I am told. Sacre-Coeur church has been under construction since 1875 and is still unfinished. Stands on the high hill called Montmatre and the domes and graceful campanile are visible for many miles around. Stepped on the moving escalator and rode to the top of the hill for a penny. The huge bell is, after the Kremlin bell at Moscow, the largest in the world. From the domes and terraces one has a magnificent view of Paris and the surrounding country.

Wednesday 12-25-1918

After breakfast got into an old war battered auto with several of the boys and rode from Louis Blane Hotel to Borghese Barracks. Had lunch. Took a long walk out Avenue 
Neuilly to the west. Crossed Seine river on bridge and on towards St. Cloud to a monument, Defense de Paris. Gave two little girls fifty centime pieces. They did not seem to know what Noel or Christmas was. Went into a movie in the suburbs, American cowboy play, then back across Seine bridge east to Borghese Barracks. Had savory Christmas dinner. Came to Louis Blane on street cars. A. R. C. busy yesterday distributing presents to the needy and giving food to the emaciated. The Christ still feeds the hungry as by the Galilean sea. Yet I did not hear the story of the Child in the Manger or the Star of Bethlehem or the Three Wise Men from the East. The little town of Bethlehem forgotten here.

Thursday 12-26-1918

At hotel in forenoon attending to my office duties. In afternoon went downtown. Shop windows beginning to make displays of valuable articles. New fur coats. Red fox neckpieces appear to be very popular, strings of pearls, glittering diamonds of great value.

Friday 12-27-1918

Illiterate degenerate Paris. In this quarter it would seem a moral and educational uplift was needed. A century needed to transform such a people. I write of the Apache district where before the war many criminals lived in the sewers safely hid from police surveilance. Saw some soldiers in khaki shinning down an alley. Army deserters or perhaps A. W. 0 . $\mathrm{L}$. that is absent without official leave. Many soldiers would get lost in the big city and overstay the time granted in permits.

Saturday 12-28-1918

Usual office work in forenoon and down to business sections in afternoon. A bunch of experienced mechanics came from St. Cyr Barracks and were given rooms at Louis Blane. These men come from the vicinity of Omaha and Denver. Are mostly mechanies and cow boys and physically a splendid lot of fellows. Are generous with candy, tooth paste, toilet articles also jellies and preserves brought from the United States. Remarkable how the Americans crave for confections from home. Presumably comparable with King David's longing when hid from the Phillistines in the cave of Adullam, troubled and 
thirsty, he said, " $O$, that some one would give me a drink of water from the well of Bethlehem which is by the gate."

Sunday 12-29-1918

A general holiday in Paris. Sergeant Phillips and I took a long walk. Poverty and ignorance everywhere in this part of the city. Many residents make noisy profession of being infidels. Religion smothered by levity. Western fellows on streets in evening and some of them drank cognac and in a short time were hilarious. When they returned to the hotel about midnight they were a noisy bunch and had to be guided to their rooms. Of course some were obstreperous and wanted to fight. The racket awoke me and I went to the assistance of Sergt. Mars. Today the quarrelsome ones apologized and said they did not realize that cognac would put them into a fighting mood or make them drunk so quickly. Worse than American whiskey.

Monday 12-30-1918

Called at tailors rue Emmanuel III. Many A. R. C. men getting new uniforms. No mail from home yet. I have written a letter to my wife every night. Censorship too strict seems to me. Local residents appear to have no joys in life except in physical dissipation. Perhaps a common condition in all the big cities of Europe involved in the war.

A newly arrived doctor from the United States at mess proceeded to give other diners a dissertation on the food value of spinach. Cheers, jeers. Throw him out of dining room. Put him in St. Anne's and feed him on spinach.

Note: St. Anne's was the large city jail of Paris a part of which was used by the Americans and in which was confined army deserters and all kind of trouble makers.

Tuesday 12-31-1918

Went to bed early in evening. Did not wish to mingle with the drinking crowd. Heard glass smashing and many harsh voices on streets. Dashing rain eame and it was quiet. And so the year ends in Paris. The land of leeks and onions to disguise disagreeable tastes and odors. This section is filled with debased populace, wine drinkers. Finis 1918 as the French say. It was a night of roystering for the denizens of Canal Marten district. A. R. C. men took little part in the 
carousals. Where there were no iron shutters the large windows were smashed. Communists, anarchists, Apaches of Paris furiously raged against the laws of organized society. But for the fact that most of the able bodied men of this section had been killed on the battlefields, the ignoble mob spirit would have been greater. Sunrise in Paris at 8:08; sunset at $3: 57$.

\section{Wecinesday 1-1-1919}

\section{JANUARY}

American Red Cross, Louis Blanc Barracks or Hotel, Quartier de la Villette, 4 rue Louis Blane, Xieme Arondissment, Paris, France. Clerk and Treasurer. My diary is made of war time paper. Bought at Magasins Reunis, cost two francs twenty-five centimes. French holiday. More general observance than Christmas day. Routine office work. Papers say Gen. Pershing sent words of gratitude to Evangeline Booth for the work done in France by the Salvation Army. Reports from the Rhine show the food situation very serious. The treaty between Germany and Belgium is only "a scrap of paper" said Chancellor Bethman-Hollweg, Aug. 14, 1914.

S. O. S. Thought for this New Year's day:

We will not bow beneath the load of life.

Nor shall we haste before the whip of time.

The voice of victory sings through all the strife

And cheers our work with words sublime.

S. Francis Hartley

Sunrise $8: 08$. Sunset $3: 58$.

Thursday 1-2-1919

Sun shone and dried off streets. Long nights and short days. Went to Place de la Republique headquarters of the various English organizations. Talked with their soldiers on duty for different purposes, also their Red Cross workers. English girls, Tommywaacs, operate autos for their soldiers. There seems to be a sort of enmity between the Americans and the English and each remain in certain sectors of Paris. Read Paris editions of Chicago Tribune. Signs on many buildings reading "Abri pour personnes," meaning, a place of shelter for persons from German shells.

Friday 1-3-1919

Wrote out hotel report and gave to Lieut. Roche. Got my 
alarm clock from jeweler but it does not ring right yet. Remained up late to help Sergt. Mars who went out for evening. Turned fifty-eight franes over to Miss Robertson. Visited Invalides for fourth time. Edifice founded by Louis IX, as a home for disabled and aged soldiers of the Napoleonic Wars. Now a war museum and holds collections of ancient and modern weapons, uniforms, cannons, flags, airplanes and many trophies of the World War. Napoleon's tomb rests under the high dome.

\section{Saturday 1-4-1919}

Alarm clock worked. This agenda, diary, is silk covered but paper is poor. Good writing materials cannot be bought. President Wilson in Rome presented with a mosaic of St. Peter by Pope Benedictus VI also two copies of the canon laws.

Note: Later when I went to work at A. R. C. headquarters at Hotel Regina, the clock was left with Mr. Wells, my successor at Louis Blane. What became of it? It was the rattler which roused me from my narrow cot, with its marsh grass filled mattress, about 5:00 A. M. in order to get hotel work started. Maids to prepare breakfast, clean halls and arrange the bedding. The drivers of autos and ambulances met all incoming trains to care for American soldiers, take them to hospitals, hotels or wherever they might wish to go. Many American officers visited Paris who were not acquainted with the city.

Sunday 1-5-1919

Rained all day. Very quiet in hotel. Retired early. It is night all day in Paris. Fellows spending their money.

Dice throwing frequent. James Harrington cleaned the gambling bunch one night recently and brought me the money, about five hundred francs. Said he wanted it sent home. Next morning I went to Equitable Trust Company of New York, Paris Branch, and bought a draft for him, payable to his sister which was mailed to Chicago, his home.

Monday 1-6-1919

Will learn French numbers and days of the week through keeping this diary bought at a store in Place de la Republique. Sergt. Mars went to Borghese Barracks at Neuilly to visit Sergt. Burnette before the latter starts back to Chicago. Two 
of Sergt. Burnette's sons are in hospitals here fearfully mangled by shell, yet living. He is not permitted to see them in France and goes home on a different vessel. The tragedies of war. Kismet. News of the death of Theodore Roosevelt received. It was expected he would visit Paris soon. Took in eighteen franes cash for lunches from transients, fifteen francs charged on books. Gave Miss Robertson seventy-two francs.

Tuesday 1-7-1919

In office all day while Sergt. Mars slept. Made loan to Capt. Young. Has been appointed to a station in Vosges sector. President Wilson visited and spoke at Turin, Italy, on his return trip from Rome. Crap shooters huddle in action tonight.

Note: Capt. Young made a long auto trip to the front, caught cold and was quite sick with pneumonia. After recovering returned home. A genial comrade.

Wednesday 1-8-1919

Assisted in hanging a large American flag in front of hotel. Usual crowd of A. R. C. men also soldier with a few French for dinner. Walked to Place de la Republique then to Place de la Opera, then home to Louis Blanc. Bought hair quinine and gloves for Sergt. Mars. Mrs. A. accidently cut her hand. Loaned her a new linen handkerchief to bandage it. Loans are keeps with many French maids.

Thursday 1-9-1919

Pleasant duties in hotel but I have to be alert and persistent. No mail from home since coming to Paris and it is two months today since our company got aboard the La Lorraine in New York Harbor. Not a single letter has been received by any member of Company B to date. Several have cabled home to ascertain why the long delay. It is found to be caused by the red tape in handling the mail. Apparently every piece is censored.

Friday 1-10-1919

Went to business district and got new uniform from tailors at rue Emmanuel III. Visited Trocadero a magnificent modern structure standing on the north bank of the Seine river. A great oriental building with a round center and two high minarets erected for the Exhibition of 1878. It has a large 
concert hall with a wonderful organ and museums of sculpture. The gas lamp lighter starts his work at 3:30 P. M.

Saturday 1-11-1919

Big rush at noon lunch. Took in ninety francs. Nice day which is to say it did not rain. New French housekeeper came. Anxious to learn to speak English language. Husband killed at Verdun. Walked along canal Marten. Women in flat boats or on banks washing clothes in icy water of canal. A Frenchman blind in one eye to whom I gave a fruit cake taken from my holiday box on Christmas day brought me a small piece of a German shell. Very heavy. Out of the sky Good Friday at St. Gervais, he said, mostly in sign language.

Note: On June 6, 1919, the day I left Paris on homeward trip workmen were just starting to repair damages done by the long range guns of the Germans to the ancient stone church of St. Gervais. It stands near the north bank of the Seine. Shelled March 29, 1918. Good Friday services were being held and some seventy-five people were killed and ninety injured by exploding shells fired from cannon some sixty miles away. Ceremonials were under way, the alter duly lighted by flickering candles to be extinguished one by one as the services progressed to commemorate the death of Christ. The organ sounded and the chorus was about to begin the lamentations of Jeremiah. A sudden crashing startled the worshipers. A shell from the Hun's guns had struck the roof. Those killed were mostly children. Cannon was located at the forest of St. Gobain. Bombardment continued for about one week when the big guns were located by the Allies aireraft and destroyed. Sunday 1-12-1919

Paid Sergt. Tim Buckley twenty-five francs for puttees. Gave kitchen maids tips seven franes fifty centimes each. Money donated by the boys. Mr. Phillips gave me fifteen francs for Mr. Repperts puttees which were left with me to sell. World's Peace Conference opened. President Wilson in Paris. Early this morning while the streets were dark and quiet a French woman, presumably going to her daily work and perhaps patriotically enthused over President Wilson's presence in Paris, passed the barracks singing in strong and vibrant tones the Marsellaise, the national anthem of France, 
the French people's song of freedom. Its striking words and moving music have made a victorious common people from the Revolution to the defense of Verdun and to final triumph in this war. I assume the singer was one who had seen better days, perhaps on the stage or in some chorus, one who had suffered bitterly from the war, for intoned in every word was the exalted and triumphant spirit of victory.

Ye sons of freedom, wake to glory!

Hark! Hark! what myriads bid ye rise!

Your children, wives and grandsires hoary,

Behold their tears, and hear their cries!

Shall hateful tyrants, mischief breeding,

With hireling host, a ruffian band,

Affright and desolate the land,

While peace and liberty lie bleeding?

Chorus

To arms, to arms, ye brave!

The avenging sword unsheathe!

March on, march on! all hearts resolved

On victory or death!

Monday 1-13-1919

Gave Mr. Reppert fifteen francs received from Mr. Phillips yesterday for puttees. Mailed French newspapers to Prof. Hukil for West Side Public Schools; Waterloo, Iowa. No mail from home has been received by the boys. Complaining. President Wilson gone to Rome to be guest of Italy's King, Victor Emmanuel. A depressing ballad had been sung by the soldiers when in the trenehes and they sang it in earnest variously worded.

I want to go home, I want to go home,

The shells they whistle, the big guns roar,

I don't want to fight the Huns any more.

Take me back over the sea to my own countrie.

oh my, I shall surely die, I want to go home.

It was changed into a plaint by Red Cross workers to run-

I want to go home, I want to go home,

The shells don't whistle

The cannons'don't roar,

I don't want to drive a truck any more.

Take me over the sea

Where Paris girls can't woo me.

Oh my! what if I die?

I want to go home. 
Tuesday 1-14-1919

Went downtown to see American Red Cross dentist. Dated me to call Thursday at $3 \mathrm{P}$. M. On metro to Borghese Barracks and bought new cap at commissary and some A. R. C. badge pins for the maids at Louis Blanc Barracks. Hotel girls have little or no jewelry and it pleases them to possess A. R. C. pins which show they are in the employ of the Americans. A. R. C. dentists are busy doing work, for all classes of Americans connected with the army, free of charge.

Wednesday 1-15-1919

In afternoon took walk on rue Fauberg du Temple. Am studying French language with the stewardess who has charge of all groceries and food supplies. She invited me to visit the cellar, a real French cave or rather prison, as the entrance ladder could be withdrawn. It is said hospice drunks were confined in this cellar and if one died the body was put into a big sewer connecting with the basement and it would be floated into Canal Marten, then to river Seine. Heavy wrought iron bars at windows. Cleaned mud off shoes, a common task.

Thursday 1-16-1919

At hotel desk in forenoon. In afternoon kept my date with A. R. C. dentist at his office rooms near the Madeleine. Two teeth repaired. For the first time saw the sun rise in Paris. Shone over house tops and church domes. Studied French lesson in Graphic. Marshall Foch suggests some new armistice terms.

Friday 1-17-1919

Sergt Mars out last night with friends and I remained up until one o'clock A. M. Made a roaring coal fire to overcome, if possible, the extreme dampness in office and dining rooms. Fired "Frogs", who were swiping hotel coal. Received my first letter from wife which was dated December 14, 1918, over one month on way. Sergt. Mars also received letter from home. A very nice day considering it is Paris, France, the land of no sunshine, at least in the winter time. President Wilson is not here as a conqueror but for the healing of the nations. Forty different plans suggested for a league. I covet the hooded capotes the policemen and many citizens wear on rainy days. Dark blue with an oil cloth lined shoulder 
cape which can be placed over one's head when a sudden shower comes.

\section{Saturday 1-18-1919}

In afternoon walked to Place de la Republique. Talked with English soldiers. A Paris fog is nothing compared with a London fog they say. Also took in sights along rue Fauberg du Temple, the street of sorrows. A. R. C. driver hilariously drunk came to barracks late at night trying to sing the Star Spangled Banner. Said he had heard a French girl singing it. World's Peace Conference opened. President Poincare made opening address. President Wilson proposed Georges Clemenceau for permanent chairman. Lloyd George of England talked. Fivents of world wide import are enacted daily. For the future, what? Time will disclose. Remaking of the subjugated and broken nations. Boundary lines. Racial lines. New maps.

Note: At the final adjustment of boundary lines by the Peace Conference the following submerged countries of Europe with the remnants of their respective races of people were resurrected and re-established,-

$\begin{array}{ll}\text { Albania } & \text { Jugoslavia } \\ \text { Czecho Slovakia } & \text { Latvia } \\ \text { Esthonia } & \text { Lithuania } \\ \text { Finland } & \text { Poland }\end{array}$

Sunday 1-19-1919

Alarm clock stopped but I was up at usual time. Forgot to wind it last night. Why? Drivers brought me some choice wine. Found in a cave near battle lines, they said. Very possible. Gave kitchen women six franes each, tips. Wrapped up and mailed home some illustrated French papers. These frugal French let no crumbs fall from their tables. The soup soured, a little vinegar was added and it was called sour soup. Waiters assured the boys it was delicious nutriment, however, very little was eaten. Humming old religious chansons these maids go about their duties momentarily forgetting the sorrows of war. They are generous with the little courtesies which imperceptibly gladden life. 
Monday 1-20-1919

A white frost in Paris. The wine drinker who was fired from the hotel for being drunk recently begged to be allowed to come back. Not permitted. Sent home to U. S. Went to Gaumont Palace to movie in evening. American play and partly an American audience. The chef de claque, a hired applause maker, stirred up a little enthusiasm and then there was a fifteen minute intermission to allow the thirsty ones to gather arojund the wine tables to gossip, perhaps to discuss the play but more I believe to display their fine elothing. No free programs. Cost a half frane and the usher expects a tip in addition. Luncheon for President Wilson at Luxemberg Palace. French papers say the Kaiser should be tried in court for crimes committed against France and her people.

Tuesday 1-21-1919

Bought French and English papers. Mailed letters for guests at local P. O. After dinner rode downtown in auto with Sergts. A. W. Marqua and Payne. Bought candy, etc., at U. S. commissary. Lieut. Anderson left barracks to live at Hotel Richmond, 11 rue du Helder, Y. M. C. A. hostelry for officers. Sergt. Tim Buckley transferred to rue Borghese Barracks. On streets in evening with a leal [?] army friend. A star shot from heaven earthwards like a shell from an airplane but no one shudders now.

Wednesday 1-22-1919

After office duties went downtown with Sergt. Payne and Marqua in auto. A sight seeing trip around Paris. Saw a vitiated boulevard stroller grab up a half burned cigarette an American doughboy had discarded and rapturously puff the remainder into smoke rings. He may have been a marquis. Papers say the Kaiser is sawing wood to keep his castle warm in Doorn. German autocracy broke when the Kaiser fled to the refuge given by Queen Wilhelmina of Holland. Gen. Pershing called to Paris to serve on joint commission. When the war started in Europe there were twenty-seven countries all told and the inhabitants of these countries represented seventy nationalities.

Thursday 1-23-1919

Office work kept me busy in forenoon, in afternoon took a 
walk along Canal Marten wearing long brown gauntlet gloves I brought from U. S. Auto gloves. French people here do not seem to have any extra clothing for cold weather. Homes of poorer classes. Goose for dinner and a crowd. Received third letter from home. English coal miners threaten to strike, papers say. I am informed the coal we use in hotel comes from England and costs $\$ 70$ per ton. A French teamster with the profile of a mule who was abusing his half starved horses near barracks because they could not move a wagon heavily loaded with structural iron, received a vigorous reprimand from some Americans. The horses were fed and rested standing in the street. Then the load moved on. The drivers excuse was that they were wild army horses from Russia and balky.

Friday 1-24-1919

Sun shone all day. Cheerful after the long gloom. Capt. Ford scolded the cook. She bawled him out for being late at dinner time. Sergt. Flower who had been left in charge of St. Cyr barracks here for duty and left with a convoy going to Coblenz, Germany. Street car strike in Paris. Dorothy and Florence Cromwell, twin sisters and A. R. C. workers, after embarking at Bordeaux to go home, leaped from the steamer La Lorraine and were drowned in the Gironde river.

Saturday 1-25-1919

Cold drizzly day. Stayed up late to help Sergt. Mars. Boozing and gambling. Three letters from home. At a session of the Peace Conference in the Salle de la Paix President Wilson made a notable address in favor of a league of nations. Georges Clemenceau opposed the idea of forming such a league. European leaders civil and military would dismember Germany and divide her territory. Wilson firmly combats the suggestion. Can Wilson tame the French tiger? War, royalty; bigotry and oppression live in the same castle and ride in the same chariot. Such should be dethroned by an intelligent people, executed and interred in the same tomb.

Note: In another address on February 14th at the Foreign office President Wilson disclosed his league of nations plans. Sunday 1-26-1919

Snow falling all day and I remained in hotel: City lights failed and Capt. Ford put an electric generator into operation 
which furnished illumination for the barracks. Boys gave me eight hundred eighty franes to put in bank for them, to be returned on demand. President Wilson in auto visited Chateau-Thierry, Belleau Woods and Rheims. This evening jocund Joan came into the office with a package in her hands and said "open this magnum of wine and fill the jorums." Order obeyed. Always cheerful aged Joan generously bestows those little courtesies which, continued through life, have a happy effect upon the countenance and diffuse a mellow evening charm over the wrinkles of old age. Replying to our flatteries Joan answered, Selah.

\section{Monday 1-27-1919}

Went to Equitable Trust Co. and placed eight hundred eighty francs in bank. Bought one hundred dollar draft for Fred Bellamy to send home. Snow melting and streets are sloppy. Passing autos splatter walks and windows in the narrow lanes. Midenettes shod in high heeled shoes and silk hose cross the wet streets daintily and dry footed. Visited Louvre a noted public building and museum. In 1857 Louvre and the 'Tuilleries, the royal gardens, were united into one campus. Most of the tragic and beneficent events of French history have been enacted in the immediate vicinity. The Louvre Museum contains the richest and the rarest art treasures of the world.

Tuesday 1-28-1919

Went to business section of city in afternoon. Very muddy and disagreeable on streets. Most of the granite block paving is set on clay base and when it rains the blocks are loosened and when vehicles or pedestrians pass over them the weight shoots dirty water in every direction. One of the elderly hotel ladies showed me a photo of herself taken when she was a girl, beautiful. Now she is aged, wrinkled, bent, garrulous, but her hooked nose is unchanged.

Wednesday 1-29-1919

Remained in hotel all day. Snow and cold wind. Lieut. E. T. Bentley getting ready to go by auto to devastated regions. American Red Cross is now elosing some of its auto stations and canteens located near the former battle fields. Two A. R. C. men have recently married French girls. This makes it 
necessary for them to secure rooms outside of the barracks. The men know very little French and the girls less English. Cupids pranks.

\section{FATE}

Two shall be born the whole wide world apart, And speak in different tongues, and have no thought

Each of the other's being, and no heed.

And these o'er unknown seas to unknown lands, Shall cross, eseaping wreck, defying death, And all unconsciously shape every act, And bend each wandering step to this one endThat one day out of darkness they shall meet, And read life's meaning in each other's eyes.

Susan Mari Spaulding

Thursday 1-30-1919

Gave Louis Blane Hotel financial report to Lieut. Roche. Rode over to Place du Clichy on subway after lunch. English soldiers numerous. Double deck farm wagon loaded with fat white hogs and drawn by four skinny horses passed hotel. In evening walked over Canal Marten to Louis Blane center. Observing a crowd collecting in a large restaurant lobby, I followed. Two Apache women were having a rough and tumble fight. The gathering crowd cheered. Each combatant seemed intent on damaging the others clothing. Coats and dresses were torn, then each made a lunge for the others hat and onto the floor went both hats, then hair pulling started which brought shrieks from both fighters, then one made a two handed grab at the others hair and got her scalp, a very fine wig. Hairless she dropped on the floor and the fight was ended. Fighting over their lovers, a common occurrence, said a native. Friday 1-31-1919

Usual routine of hotel office work. Lieut. Hoelze brought me a German gas mask from Verdun. Drivers of trucks, ambulances and autos bringing to Paris from all over the hattle field sections war relics of every kind. Most of them are sent to United States by mail or express. The charge is about fourteen dollars to express home a German gun. Postage on a helmet seventy-five cents each. Mostly German, French and Italian are sent home. 
Saturday 2-1-1919

FEBRUARY

No ground hog day in France, never heard of it. Gave maids their tips twenty-five franes each to waiters. Smaller amounts to other helpers. Announced President Wilson will visit Brussells. The German colonies, Syria, Mesopotamia, Palestine and Arabia are not to be returned to the Huns, is finding of the Powers Conference. The flotsam of France seem to appear at A. R. C. headquarters and make solemn inquiries about some lost relative or friend and then pass on. Whither the quest? No home or a desolate home because someone is gone, no word, no trace. When the German drives were on more than four hundred thousand men, women and children fled into Paris, where they received food and shelter for a short time and then were seattered all over southern France. Dark days.

Sunrise $7: 42$. Sunset $4: 46$. Sunday 2-2-1919.

Thick mist. Street lamps hardly discernible. Took a short, walk on rue Louis Blanc. A quiet Sunday for ambulances. Drivers got a little amusement from a French phonograph which had been bought with proceeds of a collection. Only a few records and they were mostly dance music. Hear the question "Do the Germans know they are licked?" "Has militarism been dethroned?" Peace Conference busy.

Its Woodrow here and Woodrow there,

Just Woodrow Wilson everywhere

And Woodrow, Woodrow ean you spare

a little time today.

For nothing is exactly right till

Wilson says, O. K.

Monday 2-3-1919

Sergt. Mars went to rue Borghese Barracks to see about new uniform. On my hotel job all day and late at night. Letter from my brother, Barnette A. Wilson, Kirwin, Kansas. He asked that I send him a few relies from battlefields. After the last German retreat war relics of even small value were quickly salvaged. Unexploded shells of various sizes and weight remain corded like wood along the roadsides but informed persons know how dangerous they may be and do not 
touch them. French soldiers are at work removing and destroying explosives. German Junkers active trying to keep alive the war spirit in their country. A letter from an American mother to A. R. C. "tell me about my son." I wrote: buried at Meuse Argonne cemetery.

\section{Tuesday 2-4-1919}

Went to Equitable Trust Co. at Place de la Opera and deposited eight hundred forty franes belonging to the boys. Got several drafts for those sending money to U. S. Mailed small A. R. C. flag to wife. It was given me by one of the drivers who was going home. He stated he had carried it on his ambulance since early summer 1915 and had been careful to keep it out of the rain. That it had traveled all over the battlefield of northeast France and he would gladly take it home with him but it would be too much trouble. Visited a shop where pearls are sold. Loquacious proprietor knew his pearls. He said a string of beautiful pearls should only encircle a beautiful neck, then both are doubly beautiful. Beautiful pearls are marred by an ugly neck and a beautiful neck is made hideous by cheap pearls.

Wednesday 2-5-1919

Seven new men came over from rue Borghese Barracks. Assigned them rooms. Rained hard. Indoors all day. Keep fit for service is a sort of a motto everywhere but somehow it appears to me as though personality wins over hard work. A young girl with a basket of tiny bits of coal gleaned from the barracks ash box standing on sidewalk looks toward this hotel with a grateful smile. Streets are the backyards of most French homes. The front yard is a court inside the block. Undersized children, scantily clad, with faces prematurely old pass by.

Thursday 2-6-1919

In hotel all day. Sergt. Mars went to tailors to get measured for new uniform. Bought a receipt book at a local book store. Had difficulty in making French clerks understand my wants in their language. In speaking French one may use correct words but fail to accent properly. Chancellor Ebert of Germany says "We are done forever with princes and nobles and all royalty." I find some misfits among the A.R.C. personnel. 
Vaudeville actors, concert hall singers, kid glove clerks fail to function satisfactorily. The real helpful laborers are the fellows from the shops and farms who know how and are willing manual workers. Again I meet some excellent maiden ladies, the good angels of their home towns, who are restless and fickle wasting time about questions of decorum and morals while the "young village cut-ups" laugh at conventionalities and snap into their tasks with a smile of happiness that is cheering. War has no behavior code.

Friday 2-7-1919

A four-inch snow fall. French in no hurry to remove from sidewalks. Appear to enjoy shuffling through the white drifts. Children snowballing just like American youths. The Huns howling because of the demands made by allies. Trying to avoid indemnities. Claim Germany is bankrupt. Boundary lines of the European nations of today and of nations long crushed that have been resurrected are in the fire and on the anvil and will be heated and pounded and twisted and made to run over mountain ranges and through valleys forming a new chart of Europe before a treaty is signed. A fascinating occupation but in the future fearful consequences may follow. What about the self-determination of these mixed peoples?

Saturday 2-8-1919

Raw day. Natives say February is usually the most disagreeable month of the seasons. Got up in night and ordered some revelers to their ronms. A carousal in a nearby wineshop.

Heinies sang:

Ja: When we reach Paree, so near

We will drink the Frenchmans beer

Doughboy sang:

You never reached the gay Paree

But ran for home, bon gré mal gré

Frogs sang:

Oui: When we reach the vineyard Rhine

We will drink the Bosche's wine

Doughboy sang:

You never reached the castled Rhine

Nor ever drained a German stein

Red Cross Chorus:

Beer and wine, have a stein

Living in Paris is mighty fine.

Carot de Carousal. 
Sunday 2-9-1.919

Several chauffeurs hilarious last night and created a disturbance. Cognac too strong a liquor for new arrivals. Most of them apologized this morning and stated they did not realize such a tiny glass of liquor would unbalance them so quickly. Wrote to Nathan Choate, my nephew, in the army stationed in central France. American soldiers are dying at Brest and other seaports, the truck drivers say, poor shelter and sanitary conditions unspeakable.

Monday 2-10-1919

Deposited in bank nine hundred sixty-five francs for boys and myself. Talk of more war. Germans are dissatisfied. A soldier at Palace de Glace for nion lunch gave me some rhymes about battlefield experience, emotions and the end:

My old tin hat's a feelin' mighty small

If 'twas only bigger into it I'd crawl

My feet feel heavy and my knees are a 'shakin'

My body fearful and my eyes a 'blinkin'

I bite my tongue every time $I$ speak

$I$ haven't slept for most a week

Bosche bullets make me fear

The end of my trail is mighty near

In No Mans Land it's rattle and clang

I hear the shells a 'bursting zip, whizz BANG.

And he had told his buddies:

Bury me in a shallow grave

Put a white cross over my head.

And radio home to my parents dear

Your soldier son is dead

He disappeared in a chariot of shell flame

Like Elijah of sacred history. ${ }^{2}$

Tuesday 2-11-1919

Went to rue Borghese Barracks and A.R.C. Commissary and bought clothing. President Wilson received the Prince of Wales at the Murat Mansion. Walked past the edifice on my

\footnotetext{
2 Those words tell the story of the boys who died, for many were blown to atoms. Dead soldiers bodies were placed in shallow graves where they fell and a cross of their nationality erected over their transient resting place. Later the American soldiers' bodies were taken from their temporary sepulcher and placed in the permanent American Soldiers cemeteries and every grave correctly marked and records made by row and number. See Congressional Record of September 26, 1929, which gives names, organizations and complete grave location of those who were made living sacrifices for their country by militarism during the World War and now rest in the permanent American cemeteries of Europe. Report of Hon: Lloyd Thurston, Congressman from the Eighth Iowa District in the House of Representatives, Washington, D. C.
} 
way home. Guards galore. Women buyers in the vegetable market haggling over the price of a pumpkin or a mess of spinach.

Wednesday 2-12-1919

Capt. Fellows informed me that I was to transfer from Louis Blane hotel to work in an office at Hotel Regina, now American Red Cross headquarters. Thanked him for the promotion. Took a long walk to Hotel de Ville, a city hall. Passed some very ancient buildings apparently erected as forts and prisons and no doubt often occupied by citizens as places of refuge during various revolutions. Ebert of Germany says at Weimar "We will combat armed domination by force to the utmost and found our democracy on a basis of what is morally right for all our people." Lloyd George says "Germany has lost all right to her colonies." Too many scheming pied pipers here tooting their horns for followers. Opportunists.

Thursday 2-13-1919

Fire broke out in one of the large rooms on second floor, occupied by several chauffeurs about 4 o'clock A. M. Perhaps bedding of a cot ignited from big open fireplace. Mattresses and blankets were burned and one drivers clothes destroyed. The smoke from burning articles filled halls and upper floors No one injured and those on lower floor not awakened. While inmates of the room who had been joined by others were fighting the fire, a French fire engine arrived carrying about a dozen firemen, pompei, the French called them. Instead of immediately attaching hose to hydrant and throwing water into room, the firemen's captain leisurely took a book from his pocket and proceeded to eall the roll of firemen's names. This delay so incensed the inmates that they proceeded to throw every article out of the windows onto narrow sidewalk and into the street and some of the burning blankets fell upon the engine. Captain wrote some data in his book and drove away. It was found a heavy oak sill near this fireplace was burning. Sergt. Mars deserves credit for his calm conduct during the exciting moments. What might have proven a serious fire was quickly controlled. About fifty people were in the hotel at the time. Several of the maids groping down 
stairway from third floor where smoke was dense were nearly suffocated.

Friday 2-14-1919

Capt. Fellows said I might be ordered to report tomorrow for new duties at Hotel Regina. A.R.C. headquarters. Am satisfied here at Louis Blane Barracks yet will welcome a change. Packed my luggage. Mailed home some pumpkin seed. Pumpkins are used by many families in this section of the city. A cheap food. Stewed pumpkin and rye bread, the diet of many poor people. President Wilson in an address at Foreign Office disclosed his plans for a League of Nations. Received an ovation. Plan denounced by Clemenceau, favored by others. The right of self-determination. The battle of Armageddon for human rights.

Note: The final triumph of Wilson's ideas over a host of opponents stands as the greatest political and moral achievement of the war. He saved Germany as a nation and restored civil political freedom to subjected people in many sections. Made a new map of Europe.

Saturday 2-15-1919

Lieut Roche, overseer of barracks department, said he could not release me for a few days from work at Louis Blane, so will have to remain longer. President Wilson left Paris on morning train for Brest and sailed on steamer George Washington for U. S. Stated he would return to Paris later.

Sunday 2-16-1919

A Sunday dinner the boys seemed to appreciate. Bought glass American jam from recent arrival. Paid one franc thirty-five centimes for it. For Chauffeur R. D. Carlysle who is sick. At Y. M. C. A. and bought candy to give poor children living near hotel. They danced with joy to get the sweets. Armistice agreement amended by a new understanding regarding Poland.

Monday 2-17-1919

R. D. Carlysle taken to hospital. Helped him to get ready and down stairs to ambulance. Drowsily he asked, am I going home, and I answered, yes, soon. Taken to American Hospital at Neuilly. A sick man. 


\begin{abstract}
Nobler and better far is he who stakes his all And takes his loss or gain as the chances fall Than he who folds his hands and idly waits Till the shadows gather darkly about his gates.
\end{abstract}

Tuesday 2-18-1919

After luncheon rather about 4 o'clock P. M. orders came from headquarters to pack my possessions and move to Borghese Barracks. Did so and was assigned to same room I occupied previously in December, 1918. Small Italian boy also has cot in room. Says his people are all dead and he wants to go to the United States.

Note: This boy spoke several languages and possessed artistic genius. He had followed the armies of various countries finally reaching American lines and in one engagement carried water to the wounded, thereby winning the good will of an American officer who eared for him and finally placed him with A.R.C. in Paris, with the wish that he might be assisted in getting to the United States. Being a dependent no one would sign the necessary guarantees required by emigration laws. Later I learned he became a protégé of Elsie Janis, the actress.

Wednesday 2-19-1919

At 9 o'clock A. M. reported to Hotel Regina for new duties. Capt. Fellows initiated me with introductions to several officers and stenographers. Dictated letters to English stenographer who spoke the French language fluently. In evening went to Louis Blanc and gave several of chauffeurs checks for money which had been left in my care and which I had placed on deposit in my account at the Equitable Trust Company bank. Tipped five dining room maids two franes each. Dressed boil on one maid's neck. It was infected from wearing an old brass chain which she had fetehed from her former hom in the devastated regions. She said it was her only piece of jewelry. Had lost her family and friends in the frantic flights toward Paris to escape the terrible Bosches. Premier Clemenceau shot seven times by Emile Cotton, anarchist. Not fatal. With others went in auto to the scene of the attempted assassination on rue Franklin. A plain brick house. 
Copyright of Annals of Iowa is the property of State of Iowa, by \& through the State Historical Society of Iowa and its content may not be copied or emailed to multiple sites or posted to a listserv without the copyright holder's express written permission. However, users may print, download, or email articles for individual use. 